\title{
THE EFFECT OF E-WOM ON SOCIAL MEDIA INSTAGRAM TOWARD THE DECISION TO VISIT LABUAN BAJO
}

\author{
Putu Gde Arie Yudhistira. \\ Program Studi Manajemen Bisnis Perjalanan. \\ Sekolah Tinggi Pariwisata Bali. \\ arieyudhistira@gmail.com
}

\begin{abstract}
E-WOM is a social media marketing especially on Instagram, which is used to promote a tourist attraction or a product. The purpose of this study was to find out the Effect of E-WOM in Social Media Instagram on the Decision to Visit Labuan Bajo. This research was a descriptive study with a quantitative approach using questionnaire tools for data collection techniques using sample of 100 respondents by taking purposive sampling technique. Respondents used in this research were visitors who had visited Labuan Bajo. This research used 2 variables: Electronic Word of Mouth variable with $5 \mathrm{e}-\mathrm{WOM}$ dimensions which were Platform Assistance, Concern for others, Expressing Positive Feeling, Economic Incentive and Helping the Company.Variable Visiting decisions were analyzed using multiple linear regression. The result of percentage of E-WOM in Social Media Instagram on the Decision to Visit Labuan Bajo was 20,6\% with two dimensions which had a very strong relationship toward decision to visit, which were dimension Expressing Positive Feeling and Economic Incentive.
\end{abstract}

Keywords: E-WOM, Social Media, Visiting Decision

\section{INTRODUCTION}

As time goes by, tourism in Indonesia is increasingly known and visited foreign and local tourists. Tourism in Indonesia is developed as time goes on. A tourist attraction which is developed well is Labuan Bajo. Labuan Bajo is a tourist attraction in Indonesia which has natural wealth that can attract tourists to visit Labuan Bajo to enjoy the beautiful nature in it. The number of visits is increasing each year. It can be seen in the table below:

Table 1.

Tourist Visit Data in Labuan Bajo

\begin{tabular}{llcr}
\hline No & Year & Number & \multicolumn{2}{c}{$\begin{array}{c}\text { Percentage } \\
(\boldsymbol{\%})\end{array}$} \\
\hline $\mathbf{1}$ & 2014 & 80.626 & - \\
\hline $\mathbf{2}$ & 2015 & 95.410 & $18 \%$ \\
\hline $\mathbf{3}$ & 2016 & 107.711 & $13 \%$ \\
\hline $\mathbf{4}$ & 2017 & 125.069 & $16 \%$ \\
\hline
\end{tabular}

Source: Web of Central Bureau of Statistics of West Manggarai District (Proceeded Data) 2018. 
Based on the tourist visit data in table above, tourist who visits Labuan Bajo increased every year. In 2014, tourist visits in Labuan Bajo were 80.636 tourists and in 2015 had enhancement of 18\% from 2014, whereas in 2016, It increased 13 $\%$ from the previous year and 16\% which became 125.069 visitors in 2017 .

Labuan Bajo is increasingly known by community through internet media which support to promote the attractiveness of Labuan Bajo tourist attraction. Social media users easily obtain information about Labuan Bajo, attractive places to visit. Many social users these days, such as Instagram which is a social media that should be used, there are interactions between the users through comment column or caption in photo which is posted in Instagram, it can be seen by other Instagram users so it triggers the urge to visit the same place.

The experience obtained by other people in tourist attraction cause the expectation to get the same experience, especially positive experience. With the development of industry in tourism field,social media currently brings positive effect. There are particular accounts which upload photos of tourist destination by giving information and location. Thus, it indirectly supports to promote a place or tourist destination.

A phenomenon of Indonesians is that they like sharing experience and express how they feel toward the attractiveness of tourism which can be seen in photos and caption they upload in their social media. The phenomenon is known as E-WOM Electronic word of mouth. It is a positive or negative expression toward the product, company or service and they are distributed through internet media (Kjerstin Thorson, 2006) in (Ati Mustikasari, 2017). E-WOM refers to the statement based on positive, neutral or even negative experience made by former customers and they are available in internet media through sites of web, social network, instant message, blog and others. (Jan Kietzmann, 2013)

Based on the explanation above, this research makes the title " The Effect of Electronic Word of Mouth (E-WOM) on Social Media Instagram Toward The Decision to visit Labuan Bajo".

\section{LITERATURE REVIEW Electronic Word of Mouth}

Internet Media currently connects and eases an individual to communicate and get information easily. Based on (Thurau, 2004) in (Fungkiya Sari, 2018), eWOM is communication which includes positive or negative statement experienced by potential customer or those who ever had before toward the product through internet social media. Before deciding to buy a product or service, a customer will previously search the information about the product or service. With electronic word of mouth, customer obtains the information about a product from people who have had experience toward the product without conducting face to face with each other (Ariani Z.R., 2016). After obtaining accurate and complete information, customer will conduct the purchase of the product or service. At this time, eWOM is a suitable way which is used to grow the decision in conducting the purchase. Electronic word of mouth has been considered an effective market tool to make prospective customer to buy a product or service (Erkan, 2015). 


\section{The Dimension of Electronic word of mouth (E-WOM)}

Based on the research done by (Thurau, 2004) in (Sari, 2012), E-WOM is reflected in 8 dimensions, as follow:

1. Platform Assistance

It is the platform to help an individual to obtain needed information, connect between social media users in opinion platform with the comments they give.

2. Venting Negative Feeling

It is to help customer to not experience dissatisfaction toward the expectation. Negative E-WOM occurs if a customer has a negative experience for them. They give comments in online according to the negative experience which they feel. It is to avoid other people to feel the same ways as they do.

3. Concern for Others

The concern for others is giving product information according to the fact. It is in order to avoid other people to buy products that are not suitable for their purchase.

4. Expressing Positive Feeling

It expresses positive feeling toward a product or service according to the experience. It shows happiness and satisfaction after enjoying a product or service that customer uses.

\section{Social Benefit}

Customers can write down the comment in media social and they involve in an E-WOM community. They can participate in online community. Thus, they will obtain social benefit from community member they follow.

6. Economic Incentive

The benefit from economy is the important encouragement of $\mathrm{n}$ individual's behavior and it is considered by the receiver as a reward from reward's giver. Therefore, acceptance of economic awards for E-WOM communication from a platform is a benefit of acceptance.

7. Helping the Company

In E-WOM communication, it can help a company to obtain positive review from E-WOM community. From their satisfaction, they recommend to other people according to their urge and according to their experience without any coercion. The customers feel that the company is worth it to be supported in order to get the profit according to their effort.

8. Advise Seeking

An individual reads the review or comment toward other people's experience in opinion-platform and provokes other customers to write the review because they feel the same thing toward the same product. By giving the comment according to their experience and the problem they face, it can give the answer for other customers who want to feel the same experience as they do. 
In this research, the dimensions used are 5 dimensions as follow: Platform Assistance, Concern for Others, Expressing Positive Feeling, Economic Incentive and Helping the Company which has been constructed in Figure 1.

Figure 1. Theoretical Dimension Construction

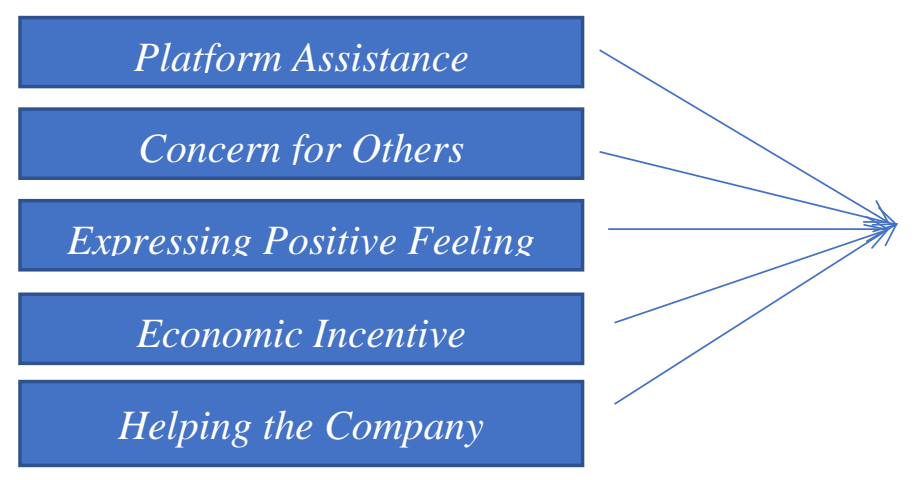

\section{The Definition of Social Media}

Social media is a new tool which is used for communication it can collaborate. It has interaction among the users (Brogan, 2010). Based on Valenza, 2004), social media is an internet platform which eases to share information quickly and to communicate between the members of community. Social media is an internetbased media which supports the relation or interaction between individual and distribution of information and communication from an individual to others.

The progress of social media is growing rapidly because internet technology is increasingly advanced. People are currently able to access social media, for example Instagram can be accessed anywhere with a smartphone. The speed to access social media replaced the role of conventional media in the dissemination of news.

There are 6 types of social media, such as social network. It is social media which helps the community to establish a relationship and interaction with individuals and groups (Puntoadi, 2011). The social media that are best known by the community Facebook, Twitter and Instagram.

Instagram is an application to share photos or videos through internet. Instagram is usually used for marketing media such as for promotions, selling online, sharing information and interacting with consumers. In Instagram, people can upload photos and videos that people want to upload. These uploads can be viewed by other Instagram users.

\section{The Decision to Visit}

The decision to conduct a tour and chose the place to visit is a decision in purchase which has freedom. According to (Hasan, 2013), there are five processes from decision making to visit that are decided by visitors as follow:

1. Introduction to the problem

This process is an initial process when the buyer is aware of a problem or needs. While knowing the problem and the needs, buyers can find out what type of product or service they need and want.

2. Information Search 
Information searched by buyers is information they need and desire.

3. Alternative Evaluation

There are some alternatives before deciding, so there is no mistake in purchasing process.

4. Purchase Decision

During evaluation process, decision will take consumers to buy products or services needed for their needs and can meet all desired needs.

5. Evaluation after Purchase

After buying product or service, consumers will provide an assessment of the performance of the product or service received according to their expectations before buying a product or service. If the performance is in line with expectations, consumers will be satisfied and if it is lower than what is expected, consumers will feel the opposite of feeling disappointed.

\section{HYPOTHESIS}

Hypotheses are conclusions or answers from the results of temporary research before being tested for truth with the results of the research and the results of data analysis.

The hypotheses formulated from the theoretical basis and research concepts are:

Ho: There is no influence from E-WOM on social media Instagram toward the decision to visit Labuan Bajo

Ha: There is influence from E-WOM on social media Instagram toward the decision to visit Labuan Bajo

From the hypotheses between the variables $\mathrm{X}$ and $\mathrm{Y}$ above, the following is the hypothesis between the variables $\mathrm{x} 1, \mathrm{x} 2, \mathrm{x} 3, \mathrm{x} 4, \mathrm{x} 5$ towards the variable results of visiting visits:

Ha1: There is an influence of Platform Assistance (X.1) on social media Instagram toward the decision to visit Labuan Bajo

Ha2: There is an influence of the Concern for Others (X.2) on social media Instagram toward the decision to visit Labuan Bajo

Ha3: There is an influence of the Expressing Positive Feeling (X.3) on social media Instagram toward the decision to visit Labuan Bajo

Ha4: There is an influence of the Economic Incentive (X.4) on social media Instagram toward the decision to visit Labuan Bajo

Ha5: There is an influence Helping Company (X.5) on social media Instagram toward the decision to visit Labuan Bajo

\section{METHODOLOGY}

The objective of the research was to find out the effect of E-WOM in Social Media Instagram toward the decision to visit Labuan Bajo. The research was qualitative descriptive research. Method used in this research was survey method with questioner instrument. Technique of data analysis used multiple linear regression.

In this research, there were 2 variables used, which were Electronic word of mouth variable which had 5 dimensions of E-WOM (Platform Assistance, Concern 
for others, Expressing Positive Feeling, Economic Incentive dan Helping the Company) and decision to visit variable.

The source of the data obtained was primary data through observation with a questionnaire involving 100 respondents who visited Labuan Bajo and those who had visited Labuan Bajo and secondary data obtained through library studies related to E-WOM, Social Media and the decision to visit Labuan Bajo.

\section{RESULT AND DISCUSSION}

\section{The Characteristic of Respondent}

The number of respondents in this research were 100 people who had ever visited Labuan Bajo.

Table 2. Gender of Respondent

\begin{tabular}{cc}
\hline Gender & $\begin{array}{c}\text { Numbe } \\
\mathbf{r}\end{array}$ \\
\hline Men & 47 \\
\hline Women & 53 \\
\hline Total & 100 \\
\hline \multicolumn{2}{l}{ Source: Processed Data $(2018)$}
\end{tabular}

From the table above, there are 47 men (47\%) and 53 women (59\%) who ever visited Labuan Bajo.

Table 3. Age of Respondent

\begin{tabular}{cc}
\hline Age & Total \\
\hline$<\mathbf{2 1}$ years & 6 \\
\hline $\mathbf{2 1}-\mathbf{3 0}$ years & 91 \\
\hline $\mathbf{3 1} \mathbf{- 4 0}$ years & 2 \\
\hline$>\mathbf{4 0}$ years & 1 \\
\hline Total & 100 \\
\hline Source: Processed Data $(2018)$
\end{tabular}

From the table above, 6 people $(6 \%)$ are $<21$ years old, $91(91 \%)$ are $21-30$ years old, 2 people (2\%) are 31-40 years old and 1 person $(1 \%)$ is $>40$ years old.

Table 4. Type of Occupation/Work

\begin{tabular}{|c|c|}
\hline Occupation & Total \\
\hline Student & 85 \\
\hline $\begin{array}{l}\text { Government } \\
\text { employees }\end{array}$ & 5 \\
\hline Private employees & 11 \\
\hline Entrepreneur & 1 \\
\hline Total & 100 \\
\hline
\end{tabular}

Based on the table above, the types of work of most visitors are 85 students (85\%), 5 civil servants (5\%), 11 entrepreneurs (11\%), and 1 entrepreneur (1\%). 
Table 5. The Visit In The Last 3 years

\begin{tabular}{lc}
\hline \multicolumn{1}{c}{ Transaction } & Total \\
\hline Once & 83 \\
\hline Twice & 11 \\
\hline $\begin{array}{l}\text { More than } \mathbf{3} \\
\text { times }\end{array}$ & 1 \\
\hline Total & 100 \\
\hline \multicolumn{2}{c}{ Source: Processed Data (2018) }
\end{tabular}

Based on the table, The number of visits to Labuan Bajo in the last 3 years is to visit once to Labuan Bajo of 83 people (83\%), 2 times of 11 people (11\%) and more than 3 times is only 1 person $(1 \%)$.

\section{Hypothesis Test}

\section{T-Test}

Tablel 6.

Coefficient Result of Hypothesis Test

\begin{tabular}{l|r|r|l}
\hline Hypothesis & \multicolumn{1}{c|}{$\mathrm{t}$} & \multicolumn{1}{c|}{ Sig. } & Result \\
\hline Platform Assistance & -.028 & .978 & Rejected \\
\hline Concern for Others & -1.345 & .182 & Rejected \\
\hline $\begin{array}{l}\text { Expressing Positive } \\
\text { Feeling }\end{array}$ & 2.773 & .007 & Accepted \\
\hline Economic Incentive & 3.404 & .001 & Accepted \\
\hline Helping the Company & -.381 & .704 & Rejected \\
\hline
\end{tabular}

Source: SPPS 20 Result (Processed)

Based on the t-test result above, hypothesis of $\mathrm{Ha} 1, \mathrm{Ha} 2, \mathrm{Ha} 5$ are rejected because $t_{\text {count }}$ value is smaller than $t_{\text {critical }}(1.984)$ and the significance value is bigger than $(0,05)$. it meant that the dimensions of Platform Assistance (Ha1), Concern For Others (Ha2), Helping the Company (Ha5) had no significant effect on the decision to visit Labuan Bajo. Whereas Ha3 and $\mathrm{Ha} 4$ are accepted because $t_{\text {count }}$ is bigger that $t_{\text {critical }}(1.984)$ and value of the significance is smaller than $(0,05)$. It meant that the dimensions of Expressing Positive Feeling (Ha3) and Economic Incentive (Ha4) had significant effect on the decision to visit Labuan Bajo.

\section{F-Test}

Limit of significant value to test the hypothesis was 0,05 . If the value is under 0,05 , Ho was rejected, if the value was above 0.05 , Ha is accepted. 
Table

\begin{tabular}{|c|c|c|c|c|c|c|}
\hline \multicolumn{7}{|c|}{ ANOVA $^{a}$} \\
\hline \multicolumn{2}{|c|}{ Model } & $\begin{array}{l}\text { Sum of } \\
\text { Squares }\end{array}$ & df & $\begin{array}{l}\text { Mean } \\
\text { Square }\end{array}$ & $\mathrm{F}$ & Sig. \\
\hline \multirow[t]{3}{*}{1} & Regression & 178.398 & 5 & 35.680 & 4.863 & $.001^{\mathrm{b}}$ \\
\hline & Residual & 689.602 & 94 & 7.336 & & \\
\hline & Total & 868.000 & 99 & & & \\
\hline
\end{tabular}

a. Dependent Variable: The decision to visit

b. Predictors: (Constant), Helping the Company, Concern for Others, Platform Assistance, Expressing Positive Feeling, Economic Incentive

Source: The result of SPPS 20 (processed)

Based on the result of the table above, the significance value of the result of the result is 001. It meant that Ho was rejected and Ha was accepted. Thus, there was an effect of E-WOM on social media Instagram toward the decision to visit Labuan Bajo.

\section{Analysis of Multiple Linear Regression}

Table 7. The Result of E-WOM Regression Analysis

\begin{tabular}{|c|c|c|c|c|c|c|}
\hline \multirow{2}{*}{\multicolumn{2}{|c|}{ Model }} & \multicolumn{2}{|c|}{$\begin{array}{l}\text { Unstandardized } \\
\text { Coefficients }\end{array}$} & \multirow{2}{*}{$\begin{array}{c}\text { Standardized } \\
\text { Coefficients } \\
\text { Beta }\end{array}$} & \multirow[b]{2}{*}{$\mathrm{t}$} & \multirow[b]{2}{*}{ Sig. } \\
\hline & & $\mathrm{B}$ & Std. Error & & & \\
\hline 1 & (Constant) & 10.795 & 3.913 & & 2.759 & .007 \\
\hline & Platform Assistance & -.005 & .175 & -.003 & -.028 & .978 \\
\hline & Concern for Others & -.190 & .141 & -.133 & -1.345 & .182 \\
\hline & $\begin{array}{l}\text { Expressing Positive } \\
\text { Feeling }\end{array}$ & .396 & .143 & .277 & 2.773 & .007 \\
\hline & Economic Incentive & .455 & .134 & .341 & 3.404 & .001 \\
\hline & Helping the Company & -.059 & .156 & -.037 & -.381 & .704 \\
\hline
\end{tabular}

a. Dependent Variable: The decision to visit

\section{Model Summary}

\begin{tabular}{lc|r|c|r} 
Model & $\mathrm{R}$ & $\mathrm{R}$ Square & $\begin{array}{c}\text { Adjusted R } \\
\text { Square }\end{array}$ & $\begin{array}{l}\text { Std. Error of } \\
\text { the Estimate }\end{array}$ \\
\hline 1 & $.453^{\mathrm{a}}$ & .206 & .163 & 2.709 \\
\hline Source: & The result of Processed Data, 2018
\end{tabular}

It is known that value $\mathrm{R}=0.453(45.3 \%)$ it showed that the relation between E-WOM variables and Visiting Decision was moderate. The coefficient of determination $\mathrm{R} 2=0.206$ showed that $\mathrm{E}-\mathrm{WOM}$ indicators (variable $\mathrm{X}$ ) on Instagram social media affected visiting decisions ( $\mathrm{Y}$ variable) of $20.6 \%$, and the remaining of $79.4 \%$ were other factors that influenced visiting decisions which were not examined in the study.

Based on the result table above it can be seen that the E-WOM Indicator that influences Bekunjung Decision was an indicator that the results were equally below 
0.05 of Expressing Positive Feeling with a result of 0.007 and Economic Incentive Indicator with a result of 0.001 .

\section{CONCLUSION AND SUGGESTION \\ Conclusion}

Based on the result of the result, it can be concluded that the result has the objective to find out how much influence E-WOM has on Instagram social media toward the decision to visit Labuan Bajo. The relationship between E-WOM variables on Instagram social media and the decision to visit is going strong. Based on the results of the research above, it can be seen that the E-WOM variable indicators that most influence visiting decisions are 2 variables that have a significant effect. They are Expressing Positive Feeling and Economic Incentive. From the result, it can be concluded that the posting photo of an individual on Instagram that shows a sense of pleasure, satisfaction and positive experience makes other people decide to visit Labuan Bajo. Getting complete information about prices or tour packages to Labuan Bajo on Instagram also makes an individual is more sure to go to Labuan Bajo because he/she has already known the details of the costs that will be spent visiting Labuan Bajo.

\section{Suggestion}

Based on the result which shows the effect of $X$ variable (E-WOM) on social media Instagram toward the decision to visit Labuan Bajo has low effect of $20.6 \%$. Hence, it is expected that further research can be assessed by adding E-WOM variables in addition to the variables used in this study. Further research also can examine the scope of the broader E-WOM not only to examine E-WOM that occurs on Instagram but research of E-WOM which includes other social media such as Facebook, Twitter and online media such as Blogs, YouTube, Online Reviews such as TripAdvisor and other online media which can be further investigated to get more complete results related to E-WOM.

\section{REFERENCE}

Ariani Z.R., W., H. (2016). The Influence of Product Attributes of Tourism and Electronic Word of Mouth (eWOM) on The Decision to Visit Parang Ijo Waterfall in Karanganyar Region,Central Java.

Ati Mustikasari, S. W. (2017). PENGARUH E-WOM TERHADAP KEPUTUSAN BERKUNJUNG KE TEMPAT WISATA DI KOTA BANDUNG. Jurnal Manajemen Indonesia, 16.

Brogan, C. (2010). Social Media 101: Tactics and Tips to Develop Your Business Online. New Jersey: John Wiley \& Sons, Inc.

Erkan, I. (2015). Electronic Word of Mouth on Instagram: Customers Engagements with Brands in Different Sectors. International Journal of Management, Accounting and Economics, 2.

Fungkiya Sari, E. P. (2018). Pengaruh Electronic Word of Mouth (E-wom) Terhadap Minat Berkunjung dan Keputusan Berkunjung. Jurnal Administrasi Bisnis, 54.

Hasan, A. (2013). Marketing dan Kasus-Kasus Pilihan. Yogyakarta: CAPS. 
Jan Kietzmann, A. C. (2013). Bittersweet! Understanding and Managing Electronic Word of Mouth Journal of Public Affairs. doi:10.1022/pa.1470

Kjerstin Thorson, S. R. (2006). Relationships Between Blogs as EWOM and Interactivity, Perceived Interactivity, and Parasocial Interaction. Journal of Interactive Advertising, 6, 34-44. doi:10.1080/15252019.2006.10722117

Puntoadi, D. (2011). Meningkatkan Penjualan Melalui Social Media. Jakarta: PT. Elex Media Komputindo.

Sari, V. M. (2012). Pengaruh Electronic Word of Mouth (eWOM) Di Social Media Twitter Terhadap Minat Beli Konsumen

Thurau, T. H. (2004). Electronic Word of Mouth Via Consumer Opinion Platforms: What Motive Consumers to Articulate Themselves On the Intenet. Journal of Interactive Marketing.

Valenza, J. (2014). Social Media Curation (Vol. 50). Chicago US: ALA TechSource. 